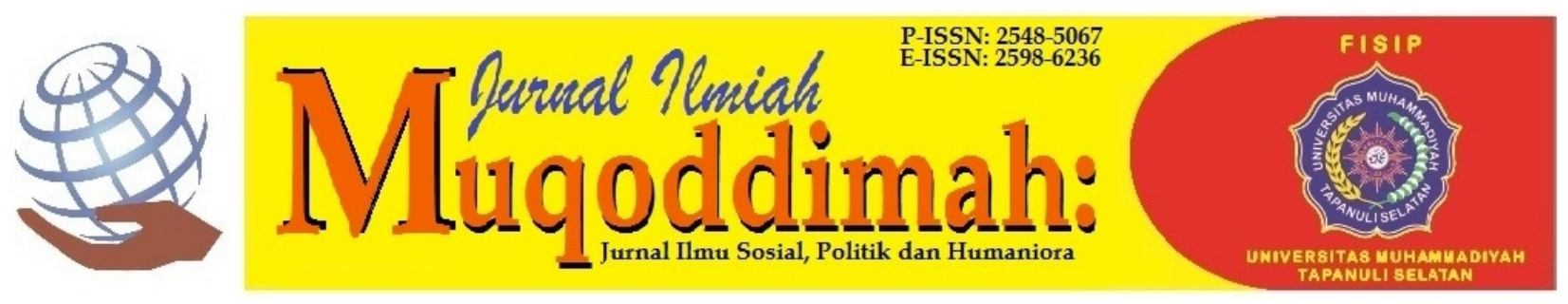

\title{
Analisis Lemahnya Kesiapsiagaan Negara Indonesia Dalam Menghadapi Bencana Covid-19 Dalam Perspektif IImu Pertahanan
}

\author{
Najib Rahman 1), Dandung Ruskar 2), Sobar Sutisna ${ }^{3)}$ \\ Universitas Pertahanan \\ Komplek Indonesia Peace and Security Center (IPSC) Sentul Bogor, Jawa Barat \\ najibrahman1106@gmail.com ${ }^{1)}$ \\ dandungruskar100@gmail.com ${ }^{21}$ \\ cdbr.idu@gmail.com@gmail.com ${ }^{3)}$
}

\begin{abstract}
Abstrak
IImu Pertahanan adalah cabang dari ilmu politik yang salah satunya mempelajari tentang ancaman baik dari luar maupun dari dalam negeri yang berasal dari unsur militer dan unsur nonmiliter. Pandemi Covid-19 ini dapat dikategorikan ke dalam ancaman negara dari unsur nonmiliter. Hal tersebut disebabkan karena serangannya sangat mendadak dan menimbulkan dampak yang luar biasa merusak seluruh sendisendi kehidupan berbangsa dan bernegara. Dampak yang ditimbulkan selain menimbulkan korban jiwa juga menimbulkan dampak krisis ekonomi, berubahnya kehidupan sosial, budaya, menurunnya mutu pendidikan, menurunnya kesejahteraan masyarakat dan lain sebagainya. Tujuan dari penelitian ini adalah menganalisis lemahnya kesiapsiagaan Negara Indonesia dalam menghadapi Bencana Pandemi Covid-19 dalam perspektif IImu Pertahanan. Metode yang digunakan dalam penelitian ini adalah Metode Penelitian Deskriptif Kualitatif dengan model Analisis Data Sekunder (ADS). Hasil dari Penelitian ini adalah ; (1) Mengetahui penyebab lemahnya kesiapsiagaan Negara Indonesia dalam menghadapi bencana Covid-19, (2) Mengetahui bagaimana cara memperbaiki kelemahan Negara Indonesia dalam menghadapi Bencana Pandemi Covid-19, (3) Mengetahui dan meningkatkan kesiapsiagaan Negara Indonesia dalam menghadapi ancaman nonmiliter yang serupa di masa yang akan datang.
\end{abstract}

Kata kunci: Covid-19, Ilmu Pertahanan, Kesiapsiagaan

\begin{abstract}
Defense Science is a branch of political science, one of which studies threats both from outside and from within the country originating from military and non-military elements. The Covid-19 pandemic can be categorized as a state threat from nonmilitary elements. This is because the attack was very sudden and had a tremendous impact damaging all the joints of the life of the nation and state. Apart from causing casualties, the impacts of the economic crisis, changes in social and cultural life, decreased quality of education, decreased social welfare and so on. The purpose of this research is to analyze the weakness of the preparedness of the State of Indonesia in facing the Covid-19 Pandemic Disaster from the perspective of Defense Sciences. The method used in this research is descriptive qualitative research method with secondary data analysis (ADS) model.. The results of this study are; (1) Knowing the causes of Indonesia's weak preparedness in the face of the Covid-19 disaster, (2) Knowing how to fix the weaknesses of the Indonesian State in dealing with the Covid-19 Pandemic Disaster, (3) Knowing and increasing the preparedness of the State of Indonesia in facing similar non-military threats in the future will come.
\end{abstract}

Key words: Covid-19, Defence Science, Preparedness 
JURNAL ILMIAH MUQODDIMAH: Jurnal Ilmu Sosial, Politik Dan Humaniora E-ISSN : 2598-6236

http://jurnal.um-tapsel.ac.id/index.php/muqoddimah
Analisis Lemahnya Kesiapsiagaan Negara Indonesia Dalam Menghadapi Bencana Covid-19 Dalam Perspektif IImu Pertahanan (Najib Rahman, Dandung Ruskar, Sobar Sutisna)

\section{PENDAHULUAN}

Dalam IImu Pertahanan, ancaman berasal dari dalam maupun luar negeri yang terdiri dari 2 unsur, diantaranya yaitu ancaman dari unsur militer dan ancaman dari unsur non-militer (Undang-Undang Nomor 23, 2019). Pandemi Covid-19 ini dapat dikategorikan ke dalam ancaman dari unsur non-militer (Indonesia, 2008) karena dampaknya melumpuhkan seluruh sendi-sendi kehidupan berbangsa dan bernegara. Hancurnya kondisi ekonomi (Nasution et al., 2020). Banyaknya korban jiwa merupakan salah satu indikator Pandemi Covid-19 ini masuk dalam peristiwa yang mengancam keutuhan dan keberlangsungan kehidupan berbangsa dan bernegara.

Bencana Non-alam (Undang-Undang Nomor 24, 2007) Pandemi Covid-19 yang terjadi sekarang ini, tidak terprediksi oleh siapapun dan oleh bidang ilmu apapun. Bencana kesehatan ini memberikan dampak yang mengerikan bagi kehidupan manusia secara keseluruhan. Tidak terlihat namun membuat seluruh dunia terperangah atas dampak bencana non-alam Pandemi Covid-19 ini. Seluruh masyarakat di dunia panik dan merespon secara cepat dengan memberlakukan berbagai antisipasi. Seluruh sumber daya dikerahkan dengan saling bahu membahu mengatasi dan meminimalisir dampak yang ditimbulkan. Dampak yang paling menyedihkan adalah hilangnya korban jiwa manusia yang merupakan kerugian paling tinggi dalam bencana (Pakpahan, 2020).

Sejak kemunculannya di bulan November di Wuhan China, Covid-19 ini dianggap berasal dari hewan liar yang dikonsumsi oleh manusia di sebuah restoran yang kemudian bermutasi pada manusia karena Covid-19 tersebut membutuhkan inang untuk hidup. Dengan strukturnya, Covid-19 ini dapat menular dari manusia ke manusia. Hal tersebut menjadikan kekhawatiran yang luar biasa bagi negara China, bahkan negara-negara di dunia. IImu pengetahuan yang belum memahami secara keseluruhan pola hidup dan bagaimana cara mengantisipasinya, menyebabkan semua orang dan negara-negara di dunia terkesan gagap menghadapi Covid-19 ini.

IImu pengetahuan modern dan teknologi modern pun tidak mampu mengendalikan secara cepat penyebaran penularan Covid-19 ini. Seluruh sumber daya dikerahkan untuk menghadapi Covid-19 ini dengan mengorbankan seluruh aspek denyut kehidupan manusia, seperti aspek ekonomi, sosial, budaya, hiburan, pendidikan (Napitupulu, 2020) dan kesejahteraan masyarakat (Gan \& Dwirahmadi, 2020).

Dalam penelitian ini penulis ingin menganalisis kelemahan kesiapsiagaan Negara Indonesia dalam menghadapi bencana non alam pandemi Covid-19 dalam perspektif ilmu pertahanan. Sejauh mana kelemahan yang ada, dan bagaimana kelemahan dalam kesiapsiagaan ini bisa segera diperbaiki dan menjadi pembelajaran bagi generasi mendatang bila bencana non alam yang serupa melanda negara Indonesia di kemudian hari (Sari, 2020).

\section{METODE}

Penelitian kualitatif adalah penelitian yang digunakan untuk meneliti pada kondisi objek alamiah, dimana peneliti merupakan intrumen kunci. Penelitian kualitatif bertujuan untuk menjelaskan fenomena melalui pengumpulan data sedalam-dalamnya. Penelitian kualitatif menekankan pada kedalaman data yang didapatkan oleh peneliti. Semakin dalam dan detail data yang di dapatkan, maka semakin baik kualitas penelitian tersebut (Sugiyono, 2005).

Dalam penelitian ini penulis menggunakan jenis penelitian Kualitatif, dengan desain penelitian menggunakan Analisis Data Sekunder (ADS) dari berbagai media dan berbagai sumber media elektronik, jurnal ilmiah, surat kabar, buku, dan media online, kemudian menganalisisnya melalui forum grup diskusi (FGD) dari berbagai sumber dan pakar secara sederhana dan ringkas (Creswell, J., 2014). 


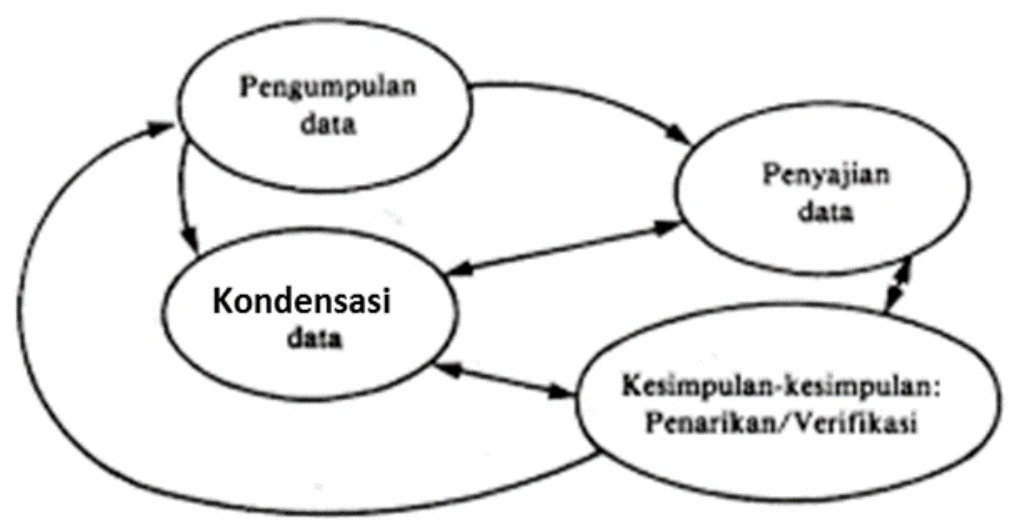

Gambar 1. Teknik Analisis Data Teknik Miles-Huberman Dan Teknik Spredley.

\section{HASIL DAN PEMBAHASAN}

Adanya kesimpangsiuran keterangan yang disampaikan oleh Presiden Joko Widodo, staf Kepresidenan Fajroel Rahchman, Menteri kesehatan dan juru bicara Kementerian Kesehatan Ahmad Yurianto di awal Pandemi sekitar awal bulan Maret 2020, menimbulkan keresahan dan keraguan di masyarakat akan adanya penyebaran Covid-19 di Indonesia (Kompas, 2020b). Dalam perspektif ilmu pertahanan segala bentuk ancaman yang menggangu kehidupan berbangsa dan bernegara baik dari dalam maupun luar negeri dapat dikategorikan ke dalam ancaman bagi negara .

Pandemi Covid-19 berdasarkan berbagai pandangan dan analisis berbagai pakar ilmu pertahanan merupakan peristiwa yang harus diwaspadai sebagai ancaman terhadap negara dalam bentuk yang baru. Dugaan konspirasi ataupun tidak harus dkaji secara mendalam. Kemungkinan invisible hand yang menyertai peristiwa ini menjadi sangat mungkin, karena tidak semua orang menyadari apa yang sedang terjadi dan apa yang akan terjadi dengan begitu cepat dengan dampak yang sangat membahayakan karena menyangkut jiwa manusia (Supriyatno, 2014).

Pernyataan kontroversial Menteri Kesehatan di awal Pandemi Covid-19 mulai masuk ke Indonesia sekitar bulan maret 2020, yaitu : (1). Bersyukur Covid-19 tak terdeteksi ; Pernyataan ini disampaikan Terawan pada 11 Februari lalu, saat virus corona belum terdeteksi di Indonesia. Terawan mengaku heran dengan wartawan yang terus-terusan mempertanyakan keberadaan virus corona di Indonesia. la memastikan pemerintah terus berusaha melakukan tes untuk mendeteksi Covid-19. Terawan pun meminta masyarakat bersyukur karena virus corona belum terdeteksi di Indonesia.; (2). Salahkan warga yang beli masker ; Pada 15 Februari, Terawan kembali menyampaikan pernyataan kontroversial saat menanggapi melambungnya harga masker. la menyebut, harga masker mengalami lonjakan karena diburu masyarakat setelah munculnya virus Corona. Terawan pun justru menyalahkan orang-orang yang membeli masker."Salahmu sendiri kok beli ya," kata Terawan di Bandara Halim Perdanakusuma, Jakarta, Sabtu (15/2/2020). Terawan menilai orang yang sehat tidak perlu menggunakan masker untuk mengantisipasi virus. Seharusnya, kata Terawan, masker hanya digunakan oleh orang yang sakit agar tak menularkan penyakitnya ke lingkungan sekitar.Hal itu sesuai anjuran Badan Kesehatan Dunia (WHO). Namun belakangan WHO pun merevisi ketentuan itu dan mewajibkan setiap orang untuk mengenakan masker saat beraktivitas di luar rumah. (3). Kekuatan doa ; 7 Februari 2020, tak hanya pakar di dalam negeri, sejumlah negara lain juga mulai mempertanyakan kenapa Covid-19 belum terdeteksi di Indonesia. Menanggapi itu, Terawan pun menyatakan kekuatan doa menjadi penyebab virus Corona tak masuk ke Indonesia."Kita ini negara yang Berketuhanan Yang Maha Esa, apa pun agamanya selama kita berpegang teguh pada Pancasila, doa itu menjadi hal yang harus utama. Maka namanya ora et labora (berdoa Volume 5, Nomor 2, Agustus 2021 
dan berusaha)," ujar Terawan. Terawan pun tak mau ambil pusing dengan pendapat negara lain."Saya kira itu tetap ada bekerja sambil berdoa. Dan itu sebuah hal yang sangat mulia. Negara lain boleh protes biarin aja. Ini hak negara kita bahwa kita mengandalkan Yang Maha kuasa," kata dia. (4). Misinformasi soal pasien 1 dan 2 ; 2 Maret 2020, Presiden Joko Widodo mengumumkan kasus pertama Covid-19 di Indonesia. Menkes Terawan turut mendampingi Presiden Jokowi saat menyampaikan pengumuman.Setelah pengumuman Jokowi, Terawan lalu menyampaikan informasi lebih detail kepada media soal pasien 1 dan 2. Terawan menyebut kedua pasien adalah ibu dan putrinya yang tinggal di Depok, Jawa Barat.Keduanya tertular dari warga Jepang domisili Malaysia yang sempat datang ke Indonesia dan berkunjung ke rumah mereka di Depok (Kompas, 2020a).

Kesiapsiagaan dan antisipasi yang kurang cepat menjadi salah satu kelemahan yang begitu terlihat mencolok, kesan pembiaran dan respon yang terlalu menganggap enteng merupakan faktor dominan dalam kelemahan kesiapsiagaan Negara Indonesia dalam menghadapi bencana pandemi Covid-19 ini (Absor, 2020).

Berikut ini kami gambarkan dinamika perkembangan kasus positif Covid-19 Mingguan dalam 5 Propinsi tertinggi di Indonesia ;

Tabel 1.

Perkembangan kasus positif Covid-19 mingguan

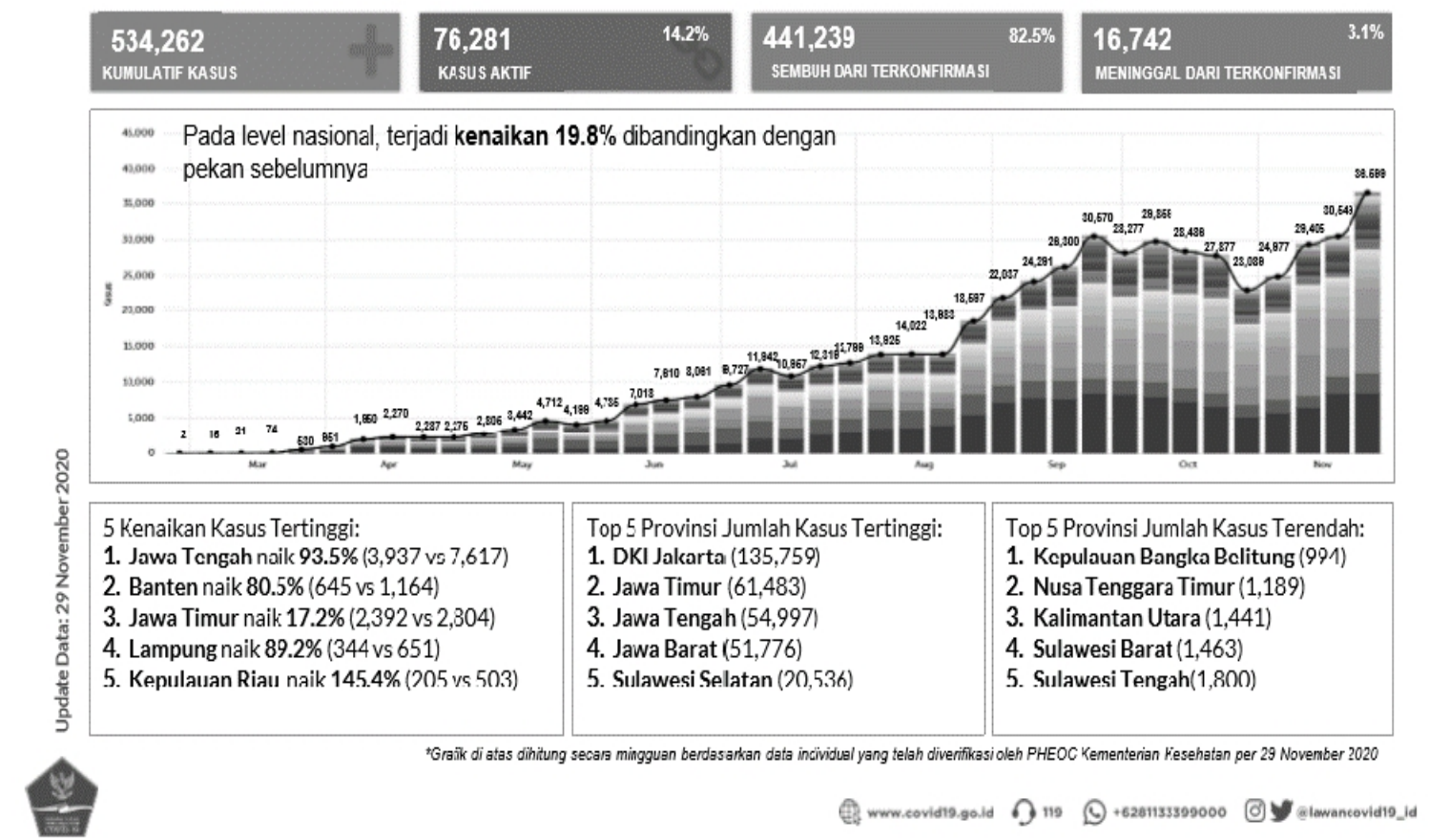

Sumber : Satuan Tugas Penanganan Covid-19 


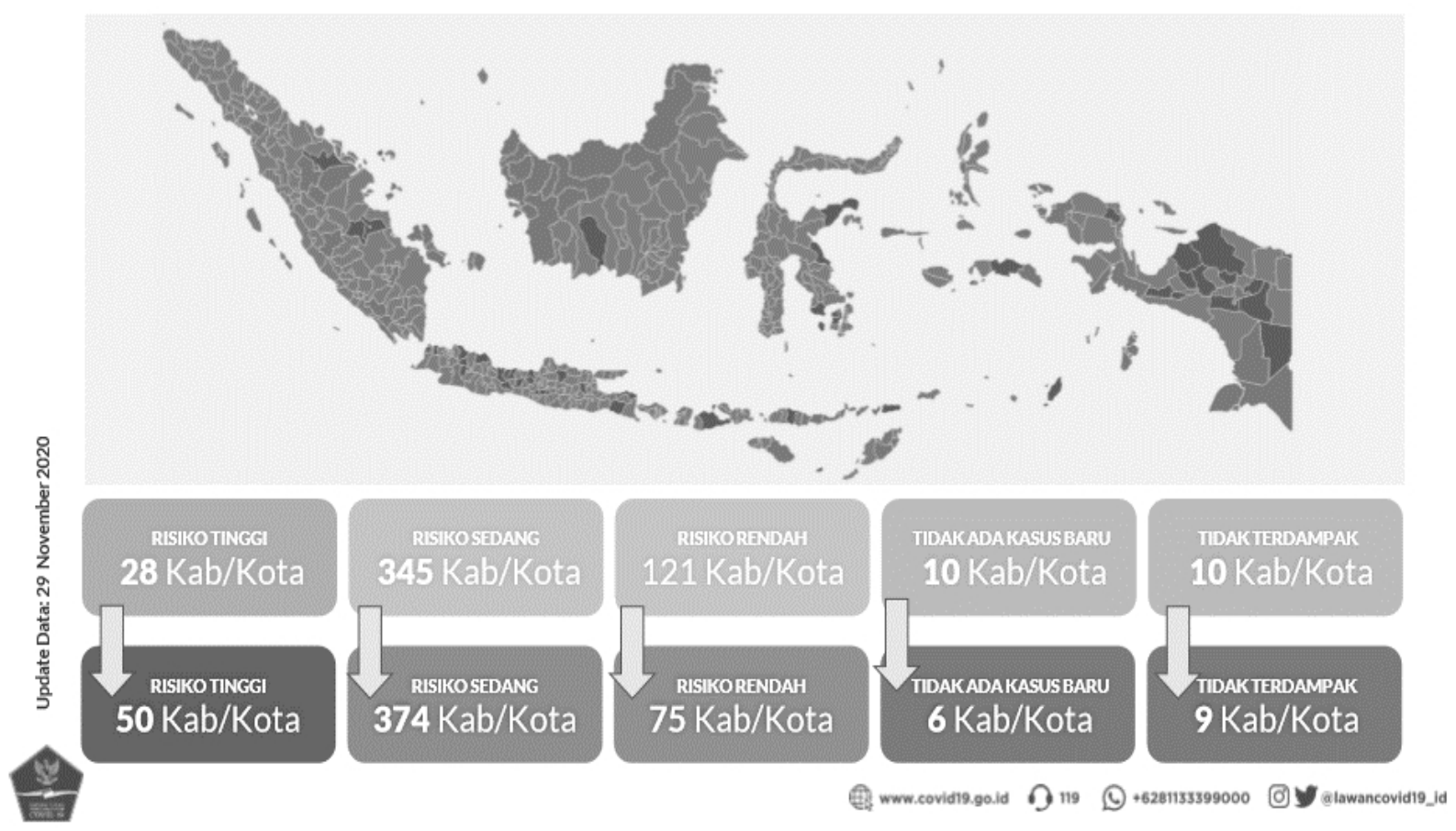

Gambar 1. Peta Zonasi Resiko Covid-19 Per 29 November 2020

\section{SIMPULAN DAN SARAN}

Secara umum bahwa llmu Pertahanan mengkategorikan Pandemi Covi 19 ini termasuk ke dalam ancanaman non militer, karena bentuk serangannya sangat tidak diprediksi dan dampak yang ditimbulkan sangat merusak kehidupan berbangsa dan bernegara. Dampak ekonomi,social,budaya, hiburan dan lainnya menjadikan peristiwa ini menjadi bahan pelajaran berharga bagi generasi mendatang bahwasannya bentuk ancaman non militer kedepan menjadi sulit diprediksi dan membutuhkan kewaspadaan dan kesiapsiagaan seluruh elemen bangsa untuk bersatu padu mengahadapi anacaman yang akana datang.

Isu Konspirasi global harus di dalami secara mendalam karena akhir dari Pandemi Covid19 ini sulit diprediksi karena merupakan hal yang baru. IImu pengetahuan dan teknologi pun belum mampu menghadapi dan mengendalikan pandemi Covid-19 secara signifikan. Berbagai penyebab kelemahan kesiapsiagaan Negara Indonesia dalam menghadapi dan mengendaliakan penyebaran Covid-19 ini diantaranya adalah : (1) Kurangnya tenaga kesehatan (2) Kurangnya laboatorium yang tersebar merata (3) Kurangnya respon cepat (4) Terbatasnya fasilitas rumah sakit (5) Tingginya jumlah penduduk (6)Tingginya mobilitas penduduk (7) Budaya berkumpul masyarakat (CNN Indonesia, 2020).

Hasil dari Penelitian ini adalah ; (1) Mengetahui penyebab lemahnya kesiapsiagaan Negara Indonesia dalam menghadapi bencana Covid-19, (2) Mengetahui bagaimana cara memperbaiki kelemahan Negara Indonesia dalam menghadapi Bencana Pandemi Covid-19, (3) Mengetahui dan meningkatkan kesiapsiagaan Negara Indonesia dalam menghadapi ancaman nonmiliter yang serupa di masa yang akan datang.

Saran yang dapat disampaikan dalam penelitian ini, diantaranya adalah; Perlunya meningkatkan Kesiapsiagaan dalam menghadapi bencana Pandemi Covid-19 maupuan bencana non alam lainnya yang serupa di masa yang akan datang. 
JURNAL ILMIAH MUQODDIMAH: Jurnal Ilmu Sosial, Politik Dan Humaniora E-ISSN : 2598-6236

http://jurnal.um-tapsel.ac.id/index.php/muqoddimah
Analisis Lemahnya Kesiapsiagaan Negara Indonesia Dalam Menghadapi Bencana Covid-19 Dalam Perspektif IImu Pertahanan (Najib Rahman, Dandung Ruskar, Sobar Sutisna)

\section{UCAPAN TERIMAKASIH}

Penelitian ini dapat terlaksana dengan lancar, berkat bantuan dan kerjasama dari berbagai pihak. Oleh karena itu, penulis mengucapkan terima kasih kepada Rektor Universitas Pertahanan yang telah memberikan keleluasaan dalam memberikan izin terkait pengembangan mahasiswa Universitas Pertahanan dalam berekspresi di bidang karya ilmiah kontemporer. Hal yang sama penulis ucapkan kepada Sekretaris Program Studi Manajemen Bencana, fakultas Keamanan nasional Universitas Pertahanan, kawan sejawat dan para Dosen yang telah membimbing dan memberi arahan secara komprehensif.

\section{DAFTAR PUSTAKA}

Absor, N. F. (2020). Pembelajaran Sejarah Abad 21: Tantangan dan Peluang dalam Menghadapi Pandemi Covid-19. CHRONOLOGIA, 2(1), 30-35. https://doi.org/10.22236/jhe.v2i1.5502

CNN Indonesia, C. N. N. (2020). Desakan RI Akui Gagal Atasi Covid Usai Dilockdown Negara Lain. nasional. https://www.cnnindonesia.com/nasional/20200909105935-20544357/desakan-ri-akui-gagal-atasi-covid-usai-dilockdown-negara-lain

Creswell, J. (2014). Research Design: Qualitative, Quantitative, and Mixed Methods Approaches. Gan, C. C., \& Dwirahmadi, F. (2020). HOW CAN THE PUBLIC BE BETTER PROTECTED AGAINST COVID-19? Jurnal Berkala Epidemiologi, $8(2), \quad 97$. https://doi.org/10.20473/jbe.V8I22020.97-99

Indonesia (Ed.). (2008). Buku putih pertahanan Indonesia, 2008: Disahkan dengan Peraturan Menteri Pertahanan, Republik Indonesia nomor PER/03/M/II/2008 tanggal 18 Februari 2008 (Cet. 1). Departemen Pertahanan, Republik Indonesia.

Kompas, K. C. (2020a). Pernyataan Kontroversial Menkes Terawan di Awal Pandemi Covid-19. KOMPAS.com. https://nasional.kompas.com/read/2020/09/29/16290701/pernyataankontroversial-menkes-terawan-di-awal-pandemi-covid-19

Kompas, K. C. (2020b, April 3). Pengumuman Mendadak Jokowi yang Kejutkan Pasien Positif Corona.

KOMPAS.com https://nasional.kompas.com/read/2020/03/04/08051361/pengumuman-mendadak-jokowiyang-kejutkan-pasien-positif-corona

Napitupulu, R. M. (2020). Dampak pandemi Covid-19 terhadap kepuasan pembelajaran jarak jauh. Jurnal Inovasi Teknologi Pendidikan, $7(1), \quad 23-33$. https://doi.org/10.21831/jitp.v7i1.32771

Nasution, D. A. D., Erlina, E., \& Muda, I. (2020). Dampak Pandemi COVID-19 terhadap Perekonomian Indonesia. Jurnal Benefita, 5(2), 212. https://doi.org/10.22216/jbe.v5i2.5313

Pakpahan, A. K. (2020). COVID-19 dan Implikasi Bagi Usaha Mikro, Kecil, dan Menengah. 6.

Sari, M. I. (2020). Implementasi Diplomasi Pertahanan Indonesia di Masa Pandemi COVID-19. $21,6$.

Sugiyono. (2005). Metode Penelitian.

Supriyatno, M. (2014). Tentang ilmu pertahanan (Edisi pertama). Yayasan Pustaka Obor Indonesia.

Undang-Undang Nomor 23. (2019). Undang-Undang Nomor 23 Tahun 2019 tentang Pertahanan Negara.

Undang-Undang Nomor 24. (2007). Undang-Undang Nomor 24 tentang Penanggulangan Bencana. 